DOI 10.22460/jpmi.v1i3.1-6

\title{
ANALISIS KEMAMPUAN KONEKSI MATEMATIS SISWA DENGAN MENGGUNAKAN MODEL PEMBELAJARAN CORE (CONNECTING, ORGANIZING, REFLECTING, EXTENDING)
}

\author{
Rifka Agustianti ${ }^{1}$, Risma Amelia ${ }^{2}$ \\ ${ }^{1}$ Universitas Nurtanio Bandung, Jl. Padjajaran No.219 \\ ${ }^{2}$ IKIP Siliwangi, Jl. Terusan Jenderal Sudirman, Cimahi, Jawa Barat, Indonesia \\ 1ifkachu@gmail.com, ${ }^{2}$ rismaamelia@ikipsiliwangi.ac.id
}

\begin{abstract}
This study aims to analyze the ability of mathematical connections of vocational students. The research population is all students of class X SMK in one of School at Cimahi City. The sample taken is one class $\mathrm{X}$ in the private SMK as the experimental class. The research method used in this study is quasiexperimental method. Instruments in this study is a set of description tests to determine the ability of students' mathematical connections. Based on result of data analysis, it can be concluded that students' mathematical ability with CORE learning model (Connecting, Organizing, Reflecting, Extending) has high category with $5 \%$ significance level.

Keywords: Ability of Mathematical Connection, learning model CORE (Connecting, Organizing, Reflecting, Extending)

Abstrak

Penelitian ini bertujuan untuk menganalisis kemampuan koneksi matematis siswa SMK. Populasi penelitian adalah seluruh siswa kelas X SMK Swasta di salah satu sekolah Kota Cimahi. Sampel yang diambil adalah 30 Siswa kelas X di SMK swasta sebagai kelas eksperimen. Metode penelitian yang digunakan dalam penelitian ini adalah metode kuasi eksperimen. Instrumen dalam penelitian ini adalah seperangkat tes uraian untuk mengetahui kemampuan koneksi matematik siswa. Berdasarkan hasil analisis data diperoleh kesimpulan bahwa kemampuan matematis siswa dengan model pembelajaran CORE (Connecting, Organizing, Reflecting, Extending) memiliki kategori tinggi dengan taraf signifikansi $5 \%$.

Kata Kunci: Kemampuan Koneksi Matematis, Model Pembelajaran CORE (Connecting, Organizing, Reflecting, Extending)

How to cite: Agustianti, R., \& Amelia, R. (2018). Analisis Kemampuan Koneksi Matematis Siswa dengan Menggunakan Model Pembelajaran Core (Connecting, Organizing, Reflecting, Extending). JPMI - Jurnal Pembelajaran Matematika Inovatif, 1 (1), 1-6.
\end{abstract}

\section{PENDAHULUAN}

Melalui proses pembelajaran matematika, siswa dituntut untuk memahami matematika secara bermakna, tidak terbatas pada satu konsep saja. Menurut Lasmawati (Lestari, 2014) mengungkapkan bahwa melalui koneksi matematis, wawasan siswa akan semakin terbuka terhadap matematika, yang kemudian akan menimbulkan sikap positif terhadap matematika itu sendiri. Melalui proses koneksi matematis, konsep pemikiran dan wawasan siswa terhadap matematika akan semakin lebih luas, tidak hanya terfokus pada topik yang sedang dipelajari. Selain itu, Gordah (Sugiman, 2017) mengatakan matematika terdiri atas beberapa cabang dan 
tiap cabang tidak bersifat tertutup yang masing-masing berdiri sendiri, tetapi suatu keseluruhan yang padu.

Koneksi matematis merupakan suatu keterampilan yang harus dibangun dan dipelajari, karena dengan kemampuan koneksi matematis yang baik akan membantu peserta didik untuk dapat mengetahui hubungan berbagai konsep dalam matematika dan mengaplikasikan matematika dalam kehidupan sehari-hari.(Siagian, 2016; Wahyu, 2014)

Uraian diatas, menggambarkan bahwa kemampuan koneksi matematika penting dimiliki oleh siswa. Namun penelitian Ruspiani (Mandur, Sadra, \& Suparta, 2013) menyatakan kemampuan siswa dalam melakukan koneksi matematis masih rendah terutama untuk koneksi antar topik matematika. Begitu pula dengan hasil penelitian Kusuma dalam Yuniawatika (Fajri, 2015) yang menyatakan bahwa tingkat kemampuan koneksi matematis siswa SMP masih rendah. Hasil penelitian tersebut menunjukkan bahwa jumlah siswa yang memiliki kemampuan koneksi tinggi masih rendah untuk setiap jenisnya.

Dengan demikian, perlu adanya sebuah model pembelajaran yang dapat meningkatkan kemampuan koneksi matematis siswa yang didalamnya terdapat aktifitas menghubungkan, mengorganisasikan, memikirkan kembali, dan memperluas wawasan dengan model pembelajaran CORE (Connecting, Organizing, Reflecting, Extending).

\section{METODE}

Metode yang digunakan dalam penelitian ini adalah metode kuasi eksperimen. Dalam penelitian terdapat dua kelompok, yaitu kelas kontrol dan kelas eksperimen. Kelas eksperimen mendapatkan perlakuan dengan menggunakan model pembelajaran core (connecting, organizing, reflecting, extending) dan kelas kontrol memperoleh pembelajaran biasa. Desain penelitiannya adalah sebagai berikut:

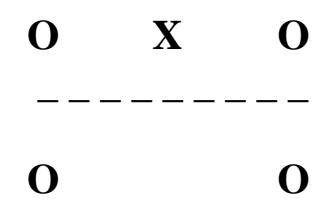

Keterangan:

O : Postes skala disposisi

X : Perlakuan dengan menggunakan PBM

_ - _ : Pengambilan sampel tidak acak

Instrumen dalam penelitian ini yaitu 5 butir soal tes kemampuan koneksi matematis. Populasi penelitian adalah seluruh siswa kelas X salah satu SMK Swasta di Kota Cimahi, sedangkan sampel yang diambil adalah 30 siswa kelas X di SMK tersebut.

\section{HASIL DAN PEMBAHASAN}

\section{A. Analisis Tes Kemampuan Koneksi Matematik}

Tes kemampuan koneksi matematik digunakan untuk mengetahui pencapaian kemampuan koneksi matematik siswa 
a. Uji Normalitas Tes Kemampuan Koneksi Matematik

Perumusan hipotesis yang digunakan pada uji normalitas sebagai berikut:

$\mathrm{H}_{0}$ : Skor tes berdistribusi normal

$\mathrm{H}_{1}$ : Skor tes berdistribusi tidak normal

Kriteria pengujiannya adalah sebagai berikut:

Jika sig. (signifikansi) pengujiannya lebih kecil dari 0,05 maka $\mathrm{H}_{0}$ ditolak

Jika sig. (signifikansi) pengujiannya lebih besar atau sama dengan 0,05 maka $\mathrm{H}_{0}$ diterima.

Adapun hasil dari analisis uji normalitas Shapiro Wilk ditunjukkan padaTabel 1 berikut:

Tabel 1. Output Uji Normalitas Tes Kemampuan Koneksi Matematik Siswa

\begin{tabular}{llccc}
\hline \multirow{2}{*}{ Kelas } & \multicolumn{3}{c}{ Shapiro Wilk } \\
\cline { 3 - 5 } & & Statistic & Df & Sig. \\
\hline Tes & Eksperimen & .942 & 28 & .123 \\
\hline
\end{tabular}

Berdasarkan output pada Tabel 1 tersebut diperoleh bahwa untuk uji Shapiro-Wilk data tes kelas eksperimen memiliki nilai signifikansi 0,123. Nilai signifikansi kelas tersebut lebih besar dari 0,05 sehingga $\mathrm{H}_{0}$ diterima artinya skor tes kelas eksperimen berasal dari populasi yang berdistribusi normal. Berdasarkan uji normalitas Shapiro-Wilk dapat diambil kesimpulan bahwa sampel berdistribusi normal sehingga dilakukan uji homogenitas.

\section{b. Uji Homogenitas Data Postes Kemampuan Koneksi Matematik}

Uji homogenitas varians dilakukan dengan uji Levene yang bertujuan untuk menunjukkan apakah data sampel memiliki varians yang sama atau tidak.

Hipotesis statistik dalam pengujian ini adalah sebagai berikut:

$\mathrm{H}_{0}:{\sigma_{1}}^{2}={\sigma_{2}}^{2}$ (Varians skor tes homogen)

$\mathrm{H}_{1}:{\sigma_{1}}^{2} \neq{\sigma_{2}}^{2}$ (Varians skor tes tidak homogen)

Selanjutnya, kriteria pengambilan keputusan untuk pengujian tersebut adalah sebagai berikut: Jika nilai signifikansi lebih besar dari 0,05 maka $\mathrm{H}_{0}$ diterima Jika nilai signifikansi lebih kecil dari 0,05 maka $\mathrm{H}_{0}$ ditolak.

Adapun output uji homogenitas varians dijelaskan oleh Tabel 2 sebagai berikut:

Tabel 2. Output Uji Homogenitas Data tes Kemampuan Koneksi Matematik Siswa

\begin{tabular}{cccc}
\hline $\begin{array}{c}\text { Levene } \\
\text { Statistic }\end{array}$ & df1 & df2 & Sig. \\
\hline 2.221 & 1 & 54 & .142 \\
\hline
\end{tabular}


Dari Tabel 2 Uji Homogenitas terlihat bahwa nilai signifikansinya adalah 0,142. Nilai tersebut lebih besar dari 0,05 sehingga berdasarkan kriteria pengujian diatas $\mathrm{H}_{0}$ diterima. Hal ini menunjukkan bahwa tidak terdapat perbedaan varians skor tes pada kelas eksperimen. Karena data tes berdistribusi normal dan homogen, maka selanjutnya dilakukan uji t satu pihak.

\section{c. Uji Perbedaan Rata-Rata Data Tes Kemampuan Koneksi Matematik}

Untuk mengetahui apakah kemampuan koneksi matematik siswa kelas eksperimen setelah diberikan model pembelajaran CORE lebih baik daripada kemampuan sebelum diberikan model pembelajaran CORE.

Hipotesis statistik dalam pengujian ini adalah sebagai berikut:

$\mathrm{H}_{0}: \mu_{1}=\mu_{2}$ Tidak terdapat perbedaan kemampuan koneksi matematik siswa sebelum dan setelah menggunakan model pembelajaran CORE (Connecting, Organizing, Reflecting, Extending)

$\mathrm{H}_{1}: \mu_{1}>\mu_{2}$ Kemampuan koneksi matematik siswa setelah mendapatkan model pembelajaran CORE (Connecting, Organizing, Reflecting, Extending) lebih baik daripada sebelum menggunakan model pembelajaran CORE (Connecting, Organizing, Reflecting, Extending)

Selanjutnya, kriteria pengambilan keputusan untuk pengujian tersebut adalah sebagai berikut: Jika nilai signifikansi lebih besar dari 0,05 maka $\mathrm{H}_{0}$ diterima

Jika nilai signifikansi lebih kecil dari 0,05 maka $\mathrm{H}_{0}$ ditolak.

Tabel 3 berikut menyajikan hasil uji perbedaan rata-rata satu pihak dengan Independent Samples T Test skor postes kelas eksperimen dan kelas kontrol.

Tabel 3. Output Uji Perbedaan Rata-Rata Data Tes Kemampuan Koneksi Matematik Siswa

\begin{tabular}{llccccc}
\hline & & \multicolumn{4}{c}{ t-test for Equality of Means } \\
\cline { 3 - 7 } & T & Df & $\begin{array}{c}\text { Sig. (2- } \\
\text { tailed) }\end{array}$ & $\begin{array}{c}\text { Mean } \\
\text { Difference }\end{array}$ & $\begin{array}{c}\text { Std. Error } \\
\text { Difference }\end{array}$ \\
\hline Postes & $\begin{array}{l}\text { Equal } \\
\text { variances } \\
\text { assumed }\end{array}$ & 6.240 & 54 & .000 & 2.821 & .452 \\
\hline
\end{tabular}

Dari Tabel 3 terlihat bahwa nilai signifikansinya adalah 0,000. Menurut Uyanto (Arifatud, Mawarsi, \& Suprapto, 2015), karena uji hipotesis yang digunakan satu pihak (one tailed) maka nilai sig (2-tailed) harus dibagi dua menjadi $\frac{0,000}{2}=0,000$. Nilai tersebut lebih kecil dari 0,05 sehingga berdasarkan kriteria pengujian diatas, $\mathrm{H}_{0}$ ditolak. Hal ini menunjukkan bahwa kemampuan koneksi matematik siswa setelah mendapatkan model pembelajaran CORE (Connecting, Organizing, Reflecting, Extending) lebih baik daripada sebelum menggunakan model pembelajaran CORE (Connecting, Organizing, Reflecting, Extending. 


\section{KESIMPULAN}

Berdasarkan hasil analisis diatas, dapat disimpulkan bahwa kemampuan koneksi matematis siswa dengan diterapkannya model pembelajaran CORE (Connecting, Organizing, Reflecting, Extending) lebih baik daripada kemampuan koneksi siswa sebelum diterapkannya model pembelajaran tersebut.

\section{DAFTAR PUSTAKA}

Anita, I. W. (2014). Pengaruh Kecemasan Matematika (Mathematics Anxiety) terhadap Kemampuan Koneksi Matematis Siswa SMP. Infinity, 3(1), 125-132. https://doi.org/http://dx.doi.org/10.22460/infinity.v3i1.43

Arifatud, D., Mawarsi, V. D., \& Suprapto, R. (2015). Implementasi Kurikulum 2013 pada Pembelajaran Model Discovery Learning Pendekatan Scietific terhadap Kemampuan Komunikasi Matematis Materi Geometri SMK. Jkpm, 2(1), 22-31.

Fajri, N. (2015). Korelasi Antara Kemampuan Koneksi Dan Komunikasi Matematis Siswa Dengan Menggunakan Pendekatan Contextual Teaching and Learning (Ctl), 2(April), 5160.

Hadriani. (2016). Pembelajaran Penemuan Untuk Mengembangkan Kemampuan Koneksi dan Disposisi Matematis Siswa SMP. Jurnal Pendidikan Matematika, 1(November), 27-34.

Kumalasari, E. (2011). Peningkatan Kemampuan Pemecahan Masalah Matematis Siswa Smp Melalui Pembelajaran Matematika Model Core. Prosiding Seminar Nasional Pendidikan Matematika STKIP Siliwangi Bandung, 1, 221-228.

Lestari, K. E. (2014). Implementasi Brain-Based Learning untuk Meningkatkan Kemamouan Koneksi dan Kemampuan Berpikir Kritis serta Motivasi Belajar Siswa SMP. Jurnal Pendidikan UNSIKA, 2(1), 36-46.

Mandur, K., Sadra, I. W., \& Suparta, I. N. (2013). Kontribusi Kemampuan Koneksi, Kemampuan Representasi, dan Disposisi Matematis terhadap Prestasi Belajar Matematika Siswa SMA Swasta di Kabupaten Manggarai. E-Journal Program Pascasarjana Universitas Pendidikan Ganesha Program Studi Pendidikan Dasar, 2.

Putri, R. M. (2017). Perbandingan Model Pembelajaran Core (Connecting, Organizing, Reflecting And Extending) Dan Discovery Learning Dalam Pembelajaran Matematika Terhadap Kemampuan Pemecahan Masalah Matematis Dan Self-Regulated Learning Siswa Sma. Repository Unpas, 16-47.

Sahrir, D. C., \& Ilmanda, M. (2017). Pengaruh Model Pembelajaran Core ( Connecting, Organizing, Reflecting, Extending ) Terhadap Peningkatan Hasil Belajar Siswa Dalam Materi Cahaya Pembelajaran Ipa Kelas V Sd Negeri 3 Cisantana, 2(September), 7-15.

Siagian, M. D. (2016). Pengaruh Penerapan Pendekatan Kemampuan Koneksi Matematik Dalam Pembelajaran Matematika. Journal Of Mathematics Educations and Science, 2(1), 58-67.

Sugiman. (2017). Kemampuan Koneksi Matematik Dalam Pembelajaran Matematika, 
6 Agustianti, \& Amelia, Analisis Kemampuan Koneksi Matematis Siswa dengan ...

(December).

Wahyu, H. (2014). THE IMPLEMENTATION OF MEAs INSTRUCTION TO STUDENTS'MATHEMATICS PROBLEM SOLVING AND CONNECTING ABILITY. In Proceeding of International Conference On Research, Implementation And Education Of Mathematics And Sciences 2014. Yogyakarta State University. 